\title{
PROGRAM PENINGKATAN KOMPETENSI WIRAUSAHA HALAL FOOD BAGI SANTRI TAHFIDZ
}

\author{
Ahmad Nurkhin, Muhsin, Satsya Yoga Baswara, dan Dwi Puji Astuti \\ Fakultas Ekonomi, Universitas Negeri Semarang \\ E-mail : ahmadnurkhin@mail.unnes.ac.id
}

\begin{abstract}
ABSTRAK
Santri hafidz membutuhkan kompetensi tambahan dalam memasuki dunia dalam kehidupan berkeluarga dan bermasyarakat. Santri hafidz harus mampu mengikuti perkembangan zaman agar tetap memiliki kompetensi dalam meraih penghasilan atau pendapatan. Baik untuk memenuhi kebutuhan keluarga maupun kebutuhan lainnya. Di sisi lain, perkembangan wisata halal food di dunia dan di Indonesia menunjukkan prospek bisnis yang menarik. Peningkatan keterampilan wirausaha halal food dapat menjadi program yang urgen untuk dilaksanakan. Oleh karena itu, kegiatan pengabdian masyarakat ini bertujuan untuk memberikan kompetensi wirausaha halal food bagi santri hafidz. Mitra kegiatan pengabdian adalah PP As Salafy Al Asror Patemon yang telah memiliki hubungan kerjasama yang baik dengan UNNES. Metode pelaksanaan kegiatan pengabdian adalah sosialisasi, praktik dan pendampingan. Sosialisasi mengenai prospek bisnis halal food, dan praktik mengolah makanan atau cake and bakery. Kegiatan pengabdian melibatkan mitra profesional di bidang halal food sehingga akan menghasilkan kegiatan yang lebih berdaya guna. Kegiatan pengabdian telah dilaksanakan di Rumah Darin Kelurahan Pakintelan Kecamatan Gunungpati Kota Semarang. Rumah Darin merupakan mitra UMKM yang terlibat dalam kegiatan pengabdian ini dan bergerak di bidang cake and bakery, khususnya dengan produk utama pie susu darin. Mitra pengabdian sebagai peserta kegiatan adalah PP Al Asror yang mempunyai santri hafidz. Kegiatan diikuti 20 santri. Kegiatan diawali dengan penyampaian materi mengenai pentingnya wirausaha oleh Bapak Dr. Muhsin dan dilanjutkan materi pembuatan roti basah dan roti kering oleh ibu Rachmawati (owner Rumah Darin). Kegiatan pengabdian dapat berjalan dengan lancar. Peserta mengikuti dengan penuh antusias. Peserta mengalami peningkatan pengetahuan dan keterampilan dalam membuat roti (cake). Kegiatan ini diharapkan dapat dilaksanakan secara berkelanjutan.
\end{abstract}

Kata Kunci : santri hafidz, halal food, bisnis syariah, santri wirausaha

\section{PENDAHULUAN}

Pesantren murupakan salah satu lembaga pendidikan Islam tertua yang sudah menjadi bagian dalam masyarakat Indonesia. Keberadaan pesantren memiliki arti penting dalam membentuk kepribadian santri agar memiliki budi pekerti yang baik (Umam, 2016). Pesantren merupakan salah satu jenis lembaga pendidikan Islam tradisional di Indonesia yang dijadikan asset pendidikan genuine bangsa Indonesia yang mampu bertahan hidup di tengahtengah modernitas yang mempunyai sub 
kultur yang unik dan khas (Sakdiyah, 2010). Pendidikan Islam yang dilaksanakan di pesantren bertujuan mempersiapkan dan menumbuhkan anak didik atau individu manusia yang prosesnya berlangsung terus menerus sehingga menjadi manusia yang berguna bagi dirinya dan bagi umatnya, serta dapat memperoleh suatu kehidupan yang sempurna (Hoerniasih, 2017).

Santri hafidz merupakan salah satu santri yang ditujukan khusus untuk menghafalkan al quran. Jika sudah selesai akan disebut hafidz atau hafidzah. Santri hafidz juga memperoleh pemahaman dan pengetahuan agama Islam dan pengetahuan lainnya saat belajar di pondok pesantren. Dengan demikian, santri hafidz akan memiliki bekal yang cukup untuk memasuki kehidupan bermasyarakat setelah tidak lagi belajar di pondok pesantren.

Pondok pesantren dapat mengelola pendidikan kewirausahaan seperti keterampilan pertanian modern, perkebunan, pertukangan, peternakan, perikanan, teknologi informasi dan lainnya, dalam menyiapkan kader alumni sebagai sumber daya insani yang kreatif dan inovatif dalam mengais rezeki setelah menamatkan pendidikannya di pondok pesantren (Umam, 2016). Kompetensi tambahan ini sangat diperlukan. Selain ilmu pengetahuan tentang Islam dan nantinya santri akan menyebarkannya, santri juga memerlukan kompetensi bertahan hidup untuk memenuhi kebutuhan hidup bagi dirinya dan keluarganya nanti.

Pendidikan kewirausahaan (entreprenuership) di Indonesia masih kurang memperoleh perhatian yang cukup memadai, baik oleh dunia pendidikan, masyarakat, maupun pemerintah (Sakdiyah, 2010). Oleh karena itu, Kemenkop dan UKM sedang dan akan terus melaksanakan program Gerakan Kewirausahaan Nasional (GKN). Termasuk di pondok pesantren, pendidikan kewirausahaan perlu diimplementasikan dengan baik dan terencana. Pemerintah sangat konsentrasi dalam mengembangkan kewirausahaan di Indonesia. Nurkhin, Kusumantoro, \& Kiswanto (2015) menyatakan bahwa pendidikan kewirausahaan harus dikenalkan sejak usia dini, termasuk pada tingkatan sekolah yang paling dasar.

Pesantren memiliki peluang penting dalam menyelesaikan permasalahan ekonomi masyarakat 
terutama dalam mengatasi masalah pengangguran yang selama ini menjadi polemik dalam masyarakat dengan memberikan pendidikan kewirausahaan kepada setiap santrinya. Para santri yang mengikuti pendidikan kewirausahaan kewirausahaan dibekali dengan pemahaman bagaimana melakukan suatu usaha, mulai dari perencanaan (planning), analisis kelayakan usaha, pelaksanaan riil (doing), pemberdayaan (empowering), pemberian fasilitasi (facilitating), serta evaluasi (evaluating) dalam setiap kegiatan pendampingan, pemberian pelatihan, motivasi dan semacamnya (Umam, 2016). Pondok pesantren telah banyak mengembangkan program kewirausahaan bagi para santrinya. Melalui pembelajaran nilai-nilai keagamaan, para santri dididik bekerja dan berusaha sesuai syariah islam. Dalam pendidikan Islam mengajarkan manusia harus memiliki keterampilan manajerial (Hoerniasih, 2017). Pondok pesantren sangat penting dalam menerapkan pendidikan kewirausahaan.

Banyak pondok pesantren yang telah berhasil menerapkan pendidikan kewirausahaan. Pondok Pesantren AnNafieciyah Kecamatan Geger Kabupaten Bangkalan yang menggunakan usaha tahu sebagai bekal wirausaha bagi para santrinya. Pesantren agribisnis al Ittifaq di Ciwidey Bandung telah berhasil menjadik pesantren penghasil aneka sayur mayur. Pesantren al Amin Prenduan Sumenep telah berhasil mengembangkan usaha bahari dengan produk berbagai aneka industri ikan laut. Pondok Pesantren Madinatun Najah Pebayuran Bekasi sebagai pesantren agribisnis. Pesantren Sidogiri Pasuruan telah berhasil melakukan pengembangan aneka usaha (Umam, 2016).

Nilai-nilai kewirausahaan yang diinternalisasikan di pondok pesantren Sidogiri adalah nilai kewirausahaan yang berbasis ibadah, dimana segala kegiatan ekonomi yang dilakukan diniatkan untuk beribadah kepada Allah SWT. Proses pendidikan kewirausahaan yang dilaksanakan dengan stategi santri dilatih untuk mengelola lembaga ekonomi yang ada di pondok pesantren di bawah pantauan dan bimbingan dari kiai dan pengurus (Chotimah, 2015). Model pendidikan kewirausahaan disusun berdasarkan karakteristik jiwa kewirausahaan santri. Pendidikan kewirausahaan ditujukan pada tiga aspek, yaitu karakter, konsep, dan keterampilan (Widodo, 2014). Model 
pendidikan kewirausahaan di pesantren yaitu Model Wirausaha Integratif (MWI) (Sujianto, 2016)

Fenomena halal food saat ini telah mengemuka. Masyarakat muslim baik di Idnonesia maupun di belahan dunia lainnya sangat membutuhkan pemenuhan kebutuhan halal food. Apalagi muslim yang sedang berwisata. Warga muslim di Indonesia telah meningkat pemahaman dan kesadarannya dalam memilih makanan yang halal. Artinya, sebagian warga muslim cenderung memilih makanan yang terdapat logo halal dalam bungkusnya atau tertempel pada rumah makan, restoran, dan lainnya. Dengan demikian, pemahaman dan pengetahuan pengolahan makanan halal sangat penting.

Pondok Pesantren As Salafy Al Asror merupakan pondok pesantren yang cukup tua di wilayah Gunungpati Kota Semarang. PP Al Asror menyelenggarakan pendidikan pesantren dan pendidikan formal lainnya, termasuk program hafidz. Berdasarkan wawancara dengan Kyai Haji Almamnuhin Kholid, pengasuh PP Al Asror, santri hafidz belum memperoleh keterampilan dalam bidang pengelolaan makanan halal, cake and bakery, dan lainnya. Santri hafidz setiap harinya berusaha untuk menambah dan mempertahankan halafan Al Qurannya. Diperlukan kegiatan tambahan baik secara sistematis maupun insidental untuk membekali santri dengan keterampilan khusus baik di bidang kuliner, teknik, jahit dan sulam, serta lainnya. Berdasarkan uraian di atas, tim pengabdian FE UNNES menganggap penting pelaksanaan kegiatan pengabdian di bidang wirausaha halal food bagi santri hafidz.

Daerah di sekitar PP Al Asror merupakan daerah yang akan terus berkembang. Keberadaan UNNES sangat menunjang hal tersebut. Meningkatnya jumlah mahasiswa UNNES menjadi faktor utama. Di samping itu, semakin banyak perumahan yang dibangun juga menyebabkan meningkatnya permintaan kebutuhan hidup, termasuk pemenuhan halal food dan lainnya. Di sekitar pondok pesantren, berkembang pesat usaha makanan dan kue. Baik dalam bentuk warung makan, angkringan, cake and bakery, maupun sejenis cafe. Fenomena ini merupakan hal menarik dan menjadi peluang bagi santri hafidz untuk mengembangkan bisnis di bidang halal food serta cake and bakery. 
Keterampilan tambahan bagi santri hafidz di PP Al Asror adalah merupakan hal yang urgen untuk diberikan. Keterampilan yang dimaksud adalah wirausaha halal food. Artinya, santri hafidz di PP Al Asror akan diberikan bekal khusus dalam pengelolaan usaha halal food serta cake and bakery. Keterampilan ini selain memberikan bekal wirausaha dan sangat prospektif, minimal dapat memberikan keterampilan memasak dan membuat kue. Kegiatan ini sangat penting karena jarang diberikan oleh pondok pesantren dan pihak lainnya.

Permasalahan yang menjadi kendala diantaranya adalah kurangnya pengasuh atau ustadz/guru yang mempunyai keterampilan di bidang halal food. Hal ini wajar, karena sebagian besar merupakan lulusan pondok pesantren atau kampus Islam yang jarang mempunyai keterampilan memasak atau membuat kue. Kendala lainnya adalah keterbatasan dalam sarana prasarana atau peralatan memasak dan membuat kue. Peralatan tersebut cukup banyak dan lumayan mahal. Pondok pesantren belum mampu memenuhi kebutuhan tersebut.

Peningkatan keterampilan tersebut akan lebih komprehensif jika dibalut dengan konsep pendidikan kewirausahaan. Banyak pesantren yang telah berhasil. Artinya, santri tidak hanya dibekali kemampuan memasak saja melainkan dibekali pengetahuan dan keterampilan mengelola usaha di bidang halal food. Santri akan mampu memasak dengan enak dan lezat, setelah itu mampu memasarkannya ke masyarakat. Keterampilan tersebut akan menghasilkan pendapatan. Bisa menjadi pekerjaan utama atau pekerjaan tambahan.

Berdasarkan paparan analisis situasi dan permasalahan mitra, maka rumusan masalah yang akan diselesaikan dalam program pengabdian ini adalah bagaimana pelaksanaan program peningkatan kompetensi wirausaha halal food bagi santri tahfidz di Kecamatan Gunungpati Kota Semarang?

Tujuan Kegiatan pengabdian kepada masyarakat ini adalah untuk Meningkatkan pemahaman dan minat wirausaha santri, meningkatkan keterampilan santri dalam bisnis halal food. Dan meningkatkan kompetensi santri dalam berwirausaha.

Khalayak Sasaran

Anggota khalayak sasarajn yang dilibatkan dalam kegiatan pengabdian 
kepada masyarakat ini adalah santri putra dan putri Pondok Pesantren As Salafy Al Asror Kelurahan Patemon Kecamatan Gunungpati Kota Semarang.

\section{METODE}

\section{Metode Pelaksanaan Kegiatan}

Kegiatan pengabdian ini dilakukan dalam bentuk workshop, pendampingan dan coaching melalui penyampaian teori secara menarik dan menggunakan media interaktif serta contoh konkret. Kemudian dilanjutkan dengan praktik mengolah makanan dan membuat kue oleh profesional. Kegiatan berikutnya adalah penyusunan business plan dan pendampingan atau coaching.

Kegiatan pengabdian ini direncanakan melalui beberapa tahapan, sebagai berikut:

1. Kegiatan awal dan persiapan

Kegiatan awal dan persiapan dilakukan oleh tim pengabdi dengan beberapa pengurus pondok pesantren dan pengasuh PP As Salafy Al Asror sebagai tempat pelaksanaan kegiatan untuk berkoordinasi awal pelaksanaan kegiatan. Hal yang dikoordinasikan diantaranya adalah tempat pelaksanaan kegiatan dan delegasi masing-masing pondok pesantren yang ada di Kecamatan Gunungpati.

2. Pelaksanaan Kegiatan Tujuan dari kegiatan ini adalah meningkatkan pengetahuan dan keterampilan mengolah makanan dan berwirausaha di bidang halal food. Kegiatan yang akan dilakukan oleh tim pengabdi adalah dengan workshop, praktik, penyuluhan, pendampingan, dan coaching.

3. Evaluasi kegiatan

Tujuan dari kegiatan ini untuk diskusi dan evaluasi dari semua tahapan kegiatan yang telah dilakukan serta rencana kedepan kelanjutan dari kegiatan pengabdian ini.

Evaluasi kegiatan pengabdian akan dilakukan secara komprehensif dimulai saat perencanaan kegiatan. Setiap tahapan akan dievaluasi dengan cara yang berbeda. Keterlibatan mitra akan menjadi salah satu indikator keberhasilan pengabdian ini. Indikator keberhasilan pelaksanaan kegiatan pengabdian akan diukur dengan tingkat keterampilan dan pemahaman peserta, yaitu lebih dari $60 \%$ peserta memiliki pemahaman dan keterampilan dalam mengolah makanan halal dan membuat 
kue serta mampu menyusun rencana bisnis yang prospektif.

Partisipasi mitra dalam kegiatan ini diantaranya adalah sebagai peserta aktif dan penyedia tempat pelaksanaan kegiatan. Pondok pesantren menentukan santri hafidznya untuk mengikuti kegiatan pengabdian. dan juga menyediakan tempat yang representatif dan mendukung pelaksanaan kegiatan. Di samping itu, mitra pengabdian dari profesional akan menjadi narasumber utama dalam praktik mengolah makanan atau membuat kue.

\section{HASIL DAN PEMBAHASAN}

\section{Pelaksanaan Kegiatan Pengabdian}

Kegiatan pengabdian kepada masyarakat ini telah berhasil dilaksanakan dengan sukses pada tanggal 7 Juli 2019 di Rumah Darin Kelurahan Pakintelan Kecamatan Gunungpati Kota Semarang. Rumah Darin merupakan mitra UMKM (mitra profesional) yang bekerjasama dalam kegiatan pengabdian ini. Produk utama dari Rumah Darin adalah pie susu darin dan menguasai bidang pembuatan cake and bakery serta halal food. Mitra utama pengabdian adalah PP Al Asror yang mempunyai santri sebagai peserta kegiatan.
Kegiatan pengabdian yang telah dilaksanakan berfokus pada peningkatan pengetahuan dan sikap wirausaha santri serta pembuatan cake and bakery, khususnya kue basah (rose tart) dan kue kering (kastengel). Kegiatan dimulai pada pukul 08.00 dan berakhir pada pukul 16.00. Kegiatan dipandu oleh pembawa acara, yaitu ibu Dwi Puji Astuti, S.Pd., M.Pd. Kegiatan dilanjutkan dengan prakata oleh perwakilan tim pengabdi dan perwakilan santri. Materi pengabdian disampaikan oleh Dr. Muhsin, M.Si. yang menjelaskan pentingnya wirausaha bagi kehidupan santri di masa yang akan datang. Materi dilanjutkan dengan teori membuat kue dan diteruskan dengan praktik membuat kue. Sebelumnya diserahkan secara simbolis peralatan membuat kue seperti mixer, oven, kompor, dan lain sebagainya.

Ibu Rachmawati, owner Rumah Darin menguraikan perjalanan usaha di bidang cake and bakery serta halal food. Pemateri telah menyiapkan resep untuk dipraktikkan oleh peserta. Namun demikian, resep hanya sebagai panduan awal agar bisa lebih mudah dalam membuat kue. Jika sudah biasa melakukan, maka peserta dapat menyesuaikan resep dengan selera dan 
kebutuhan. Pemateri juga menyampaikan bahwa usaha di bidang cake and bakery tetap menjanjikan apalagi pada momentum khusus, seperti hari raya dan lainnya. Kerja keras, kesungguhan, dan telaten merupakan kunci dalam melaksanakan bisnis.

Kegiatan berlangsung menarik dan peserta mengikuti dengan antusias. Sebagian besar santri belum pernah praktik membuat kue. Pengalaman pertama membuat peserta tidak sungkan untuk mengajukan pertanyaan. Pertanyaan yang dimaksud diantaranya adalah sebagai berikut.

1. Berapa lama campuran bahan diaduk?

2. Seberapa berpengaruh mengaduk adonan dengan tangan dibandingkan dengan alat (sendok)?

3. Cara memasukan bahannya bertahap atau sekaligus? Seberapa besar ukuran rotinya?

4. Berapa lama roti dioven dan seberapa besar apinya?

5. Bagaimana cara mengetahui roti yang sudah matang?

6. Proses apa yang harus dilakukan setelah roti keluar dari oven?

7. Seberapa besar ukuran rotinya?
8. Bagaimana cara mengemas roti yang menarik?

9. Cara memilih ujung plastik adonan (moncong) pada hiasan roti tart?

Peserta dibagi menjadi empat kelompok sesuai dengan jenis kue yang akan dibuat. Kue yang dimaksud diantaranya nastart, kastengel, dan rose tart. Pemateri telah menyiapkan bahan dan resep sesuai dengan roti yang akan dibuat. Peserta bekerjasama dengan masing-masing anggota secara sungguh-sungguh menyelesaikan pembuatan roti mulai dari membuat adonan, membuat cetakan roti, memasukkan ke oven, hingga roti telah masak. Peserta sangat bersemangat dalam mengikuti kegiatan pengabdian ini. Peserta dan pemateri berinteraksi secara langsung agar kue yang dibuat dapat berhasil. Pengalaman yang menarik dan berharga bagi santri. Tim pengabdi juga terlibat dalam pembuatan kue. Kegiatan diakhiri dengan foto bersama dan menikmati kue yang telah jadi.

Materi terakhir dalam kegiatan pengabdian ini adalah packaging. Tim pengabdian bersama mitra Rumah Darin telah menyiapkan alat dan bahan untuk packaging kue yang telah berhasil dibuat. Packaging menjadi sangat 
penting karena akan menambah nilai jual kue. Pemateri memberikan materi bagaimana mem-package kue dengan sebaik-baiknya.
Uraian pelaksanaan kegiatan pengabdian kepada masyarakat ini tersaji pada table dan gambar berikut ini.

Tabel 1. Tahapan Pelaksanaan Kegiatan Pengabdian kepada Masyarakat

\begin{tabular}{lll}
\hline No. & $\begin{array}{c}\text { Tahapan } \\
\text { Pengabdian }\end{array}$ & \multicolumn{1}{c}{ Uraian Kegiatan } \\
\hline 1. & Perencanaan & Koordinasi dengan pengasuh PP Al Asror, KH. \\
& Almamnukhin Khalid. Menentukan peserta, tempat dan \\
& waktu pelaksanaan. \\
& Koordinasi dengan owner Rumah Darin Semarang, ibu \\
& Rachmawati dan bapak Dr. Agus Wahyudin. Menentukan \\
& jenis kue, bahan dan alat, serta waktu pelaksanaan kegiatan. \\
& Koordinasi tim pengabdian, penyiapan alat dan bahan, \\
& susunan acara, dan konsumsi kegiatan. \\
& Penyampaian materi teori "wirausaha" oleh Dr. Muhsin, \\
& M.Si. \\
& Penyampaian materi teori membuat kue kering dan basah \\
& oleh ibu Rachmawati dilanjutkan dengan praktik membuat \\
& kue. \\
& Penyampaian materi packaging kue oleh ibu Rachmawati \\
& dilanjutkan praktik. \\
& Penyampaian materi menyusun business plan oleh Ahmad \\
& Nurkhin, S.Pd., M.Si. disertai contoh dan praktik menyusun \\
& rencana usaha. \\
& Evaluasi peningkatan pengetahuan membuat kue. Dilakukan \\
& langsung oleh ibu Rachmawati dengan tanya jawab langsung. \\
& Pengetahuan secara umum masih sangat dasar. \\
& Evaluasi pelaksanaan kegiatan pengabdian. Dilakukan oleh \\
& tim pengabdi. Termasuk mengamati antuasiasme peserta dan \\
& keterlibatan peserta dalam kegiatan. Peserta sangat antusias \\
dan menikmati kegiatan pengabdian.
\end{tabular}

Evaluasi Pelaksanaan Kegiatan Pengabdian

Kegiatan pengabdian kepada masyarakat ini secara umum dapat berlangsung dengan baik, dimulai dari perencanaan sampai dengan pelaksanaan kegiatan. Mitra yang diajak untuk menyampaikan materi pembuatan kue juga sangat kooperatif dari mulai penyiapan alat dan bahan sampai dengan selesai kegiatan. Pengasuh dan santri PP Al Asror juga sangat membantu pelaksanaan kegiatan pengabdian, karena telah terjalin 
kerjasama yang baik selama ini. Kegiatan pengabdian ini juga merupakan kegiatan lanjutan dari kegiatan pengabdian tahun-tahun sebelumnya.

Kesan peserta juga positif. Hal ini tampak pada kesan yang disampaikan sebagai beriktu:

1) Alim

Alhamdulillah senang dapat ilmu baru dan pengalaman baru. Ilmunya sangat bermanfaat. Jadi terinspirasi suatu saat menjadi wirausaha. Harapannya suatu saat diadakan pelatihan kembali. Alim juga menyampaikan agar kita bisa bangkit dari kegagalan dan mancari solusi dari permasalahan yang kita dapat.

2) Dina

Senang bisa jalan-jalan keluar pondok, bermanfaat untuk kedepan, jadi lebih tahu tentang membuat roti. Harapannya bisa diadakan pelatihan kembali.

3) Nisa

Bermanfaat, ingin mengaplikasikan kembali dipondok dan dirumah. Senang bisa keluar pondok dan belajar ilmu baru. Sangat bermanfaat kedepan.
Pengasuh PP Al Asror, KH. Almamnukhin Khalid juga menyampaikan terimakasih dan harapan bagi tim pengabdian, agar kegiatan pengabdian dapat dilanjutkan dengan bidang yang berbeda. Dan tentunya kegiatan yang berkelanjutan. Masih banyak permasalahan yang membutuhkan kerjasama dengan pihak UNNES dalam meningkatkan kualitas Pendidikan di pondok pesantren.

\section{KESIMPULAN DAN SARAN}

\section{Kesimpulan}

Kegiatan pengabdian kepada masyarakat telah selesai dilaksanakan pada tanggal 7 Juli 2019 dengan melibatkan mitra Rumah Darin Semarang sebagai mitra professional di bidang cake and bakery. Peserta kegiatan pengabdian adalah santri PP Al Asror. Peserta mengikuti kegiatan pengabdian dengan baik dan antusias. Materi pengabdian adalah motivasi menjadi wirausaha oleh Dr. Muhsin, M.Si., lika-liku bisnis makanan dan kue oleh Rachmawati dan dilanjutkan dengan praktik membuat kue kering dan kue basah, serta packaging kue. Materi terakhir mengenai penyusunan business plan oleh Ahmad Nurkhin, S.Pd., M.Si. 


\section{Saran}

Kegiatan pengabdian ini baru dilaksanakan sekali pertemuan dari pukul 08 pagi sampai dengan pukul 16.00. Kegiatan ini masih dianggap kurang dalam memberikan bekal pengetahuan dan keterampilan membuat kue oleh santri. Harapannya dapat dilaksanakan beberapa pertemuan disertai pendampingan dalam penjualan kue yang telah dibuat. Santri diharapkan dapat melanjutkan kegiatan pengabdian ini dengan alat dan bahan yang telah disiapkan. Mitra professional (Rumah Darin) juga diharapkan untuk dapat memberikan coaching dan pendampingan bagi santri yang mau menjalankan usaha di bidang cake and bakery. Serta pengasuh pondok pesantren diharapkan memberikan dukungan untuk meningkatkan kemampuan santri dalam berwirausaha.

\section{DAFTAR PUSTAKA}

Chotimah, C. (2015). Pendidikan kewirausahaan di pondok pesantren sidogiri pasuruan. Inferensi, Jurnal Penelitian Sosial Keagamaan, 8(1), 114-136.
Hoerniasih, N. (2017). Penerapan Nilainilai Agama Islam dalam Mengembangkan Pendidikan Kewirausahaan di Pondok Pesantren. In Seminar Nasional Pendidikan Nonformal FKIP Universitas Bengkulu (Vol. 1, pp. 94-106).

Nurkhin, A., Kusumantoro, \& Kiswanto. (2015). Model Pendidikan Kewirausahaan di SMP Alam Ar Ridho. In Seminar Nasional "Entrepreneurship dan Profesionalitas Guru di Era MEA" (pp. 247-261). Wates: FE UNY Yogyakarta.

Sakdiyah, H. (2010). Revitalisasi entrepreneurship di pondok pesantren. Al-Hikam, V(2), 275 290.

Sujianto, A. E. (2016). Model Pendidikan Wirausaha di Pesantren. In The International Conference on UniversityCommunity Engagement (pp. 2-5). Surabaya.

Umam, K. (2016). Pendidikan Kewirausahaan di Pesantren sebagai Upaya dalam Membangun Semangan para Santri untuk Berwirausaha. EKSYAR: Jurnal Ekonomi Syari'ah, 3(1), 47-64.

Widodo, S. (2014). Model pendidikan kewirausahaan bagi santri untuk mengatasi pengangguran di pedesaan. Mimbar, 31(2), 171179. 